\title{
Correlation Between Spiritual Intelligence and Self-efficacy Patients with Coronary Artery Disease
}

\author{
Wantiyah Wantiyah, Wiwit Ulansari, Fitrio Deviantony \\ Faculty of Nursing, Universitas Jember, Jember, Indonesia \\ Corresponding Email:wantiyah.psik@unej.ac.id
}

Submitted: 24-07-2020 Accepted: 16-09-2020 Published: 01-12-2020

\begin{abstract}
Coronary Heart Disease (CHD) is a cardiovascular disease affecting the patient's life both psychologically and physically. Therefore it can reduce patients' quality of life. Self-efficacy is one crucial factor that can improve the quality of life of patients with CHD to control risk factors. spiritual intelligence can make a person more able to interpret the life and have a positive meaning in each event, to improve the quality of life. This study used a descriptive correlation research design with a cross-sectional approach. This research involved 138 CHD patients as respondents in RSD dr. Soebandi of Jember, East Java, Indonesia, obtained by accidental sampling method. Data were collected using a Spiritual Intelligence questionnaire and Cardiac Self-Efficacy (CSE). The analysis of data used is Somers'd test with a confidence level of $95 \%(\alpha: 0.05)$. Respondent characteristics include age, gender, marital status, education, occupation, income, smoking history, and disease history. The results showed that $86.2 \%$ of CHD patients had high self-efficacy, and 55\% of CHD patients had high spiritual intelligence. Analysis shows there is a strong correlation between spiritual intelligence and self-efficacy $(\mathrm{p}=<0.001, \mathrm{r}=0.628, \alpha$ : 0.05 ). The patients having high spiritual intelligence will have high self-efficacy. Spiritual intelligence comes from within the patient, which can be developed to improve the self-efficacy of CHD patients through the provision of holistic nursing care. Therefore, it is expected for nursing staff to assess patients' spiritual intelligence, so they can provide appropriate nursing care so that patient self-efficacy can be improved, and patient health can be optimized.
\end{abstract}

Keywords: Coronary artery disease, self-efficacy, spiritual intelligence. 
Wantiah: Correlation between Spiritual Intelligence and Self-efficacy Patients with Coronary Artery Disease

\section{Introduction}

Coronary Heart Disease (CHD) is a disease that occurs when the coronary artery walls are narrowed due to a buildup of plaque that can cause heart attacks (American Heart Assosiation, 2015). World Health Organization noted that 17 million people died in the world due to heart and blood vessel disease. It is around $31 \%$ of deaths in the world, most or 8.7 million, are caused by coronary heart disease, and more than $75 \%$ of deaths are caused by heart and blood vessel disease (Kementrian Kesehatan Republik Indonesia, 2018).

East Java Province in 2013 became the region with the most coronary heart disease sufferers totaling 375,127 people (Kementrian Kesehatan Republik Indonesia, 2014). CHD is a chronic disease having an impact on the physical and psychological condition of the patient. The physical impact can be in the form of chest pain and disruption of activities, while in terms of the psychological type of anxiety and depression to make patients afraid of death (Hamzah, Dewi, \& Suparno, 2014). The physical and psychological impacts can worsen the patient's condition, so it is essential to do good self-management. Good self-management can be done with strong self-efficacy(Pencina et al., 2019; Xu, Kwan, \& Leung, 2019).

Self-efficacy has a vital role in helping coronary heart patients encourage patients to control themselves and maintain behaviors that support the improvement of CHD patients' health. Sari, Sari, \& Pratiwi research results (2017) showed that the majority of respondents $(62.86 \%)$ had high selfefficacy and had moderate risk factors for cardiovascular disease Wantiyah's (2010) research, states that self-efficacy is related to the maintenance of function and prevention of risk factors.

Not only physical aspects but psychological aspects in CHD patients also have an essential role. Positive mental health can affect physical health because good psychological health will positively and happily make a person think positively. Positive mental health includes psychological health aspects, emotions, positivity, life satisfaction, optimism, life goals, social support, and spirituality (Park et al., 2014). Psychological factors that can affect the quality of life of CHD patients are spiritual intelligence originating from within oneself to support self-efficacy (Nekouei, Yousefy, Neshat Doost, Manshaee, \& Sadeghei, 2014).

A study has revealed that individuals with better spiritual inclinations can respond when faced with damage, control stresses better, and have better health (Saam \& Wahyuni, 2012). Norouzi \& Azar (2017), show that there is a significant positive relationship between spiritual intelligence and emotional expression, especially positive emotional expression $(\mathrm{p}<0.05)$. In chronic patients with spiritual intelligence will have an impact on physical and mental stress, lead to adaptation and elimination of stress or reduction of stress and anxiety in patients by forming patient adaptations. This is supported by research by (Dev et al., 2018), which states that there is a relationship between spiritual intelligence and healthy behavior with a significance of $p$ $=(0.0001)$.

Even though there are researches find that spiritual intelligence can influence patients' response to their disease. However, researches focus on how spiritual intelligence can influence self-efficacy in a patient with CHD are still limited. Spiritual intelligence, which impacted on the patient's belief about their ability to improve their health, has a good influence on the psychology of CHD patients. It was the goal of health management for CHD patients. Hence, researchers are interested in finding the relationship between spiritual intelligence and self-efficacy in coronary heart disease patients. According to that point, the resulting study of the relationship between spiritual intelligence and selfefficacy is expected to be a consideration in providing nursing care for CHD patients.

\section{Method}

The design used in this study is descriptive correlational with non-experimental design and using a cross-sectional approach. This study has two variables: selfefficacy (dependent variable) and spiritual intelligence (independent variable). This study's population was all coronary heart 
disease patients recorded in the Cardiology Polyclinic of hospital dr. Soebandi of Jember. The $G$ *Power application 3.1.9.4 calculated the number of samples. Based on calculations using $\mathrm{G} *$ Power 3 with a standard effect size of 0.3 , an error probability using 0.05 , and power (1- $\beta$ error probability) using 0.95 obtained a sample of 138. The samples were collected using an accidental sampling technique.

This research was conducted at Cardiology Polyclinic of RSD dr. Soebandi, of Jember Regency from September 2019 to January 2020, and research data collection was carried out from January to February 2020. The data were collected using a standardized, validated, and reliable to use questionnaire, namely the spiritual intelligence questionnaire by Kurniawati (2018), in her research entitled "The Effect of Mind-Body-Spiritual (MBS) Nursing Care on Spiritual Intelligenc; Expressions of Hsp 70, eNOS, VCAM1 , and MCP-1 in patients with coronary heart disease" with the reliability test, the Cronbach alpha value was 0.639-927, and the
CSE (Cardiac Self Efficacy) Questionnaire by Wantiyah (2010). The results of the CSE questionnaire reliability test Cronbach alpha value of 0.77 .

The questionnaire test results are reliable if the Cronbach alpha value $>0.7$ (Pamungkas \& Usman, 2017). The data from the spiritual intelligence questionnaire and CSE can be used as a measurement tool. The results of the age normality test conducted by the researcher indicated a $p$-value of 0.200 , which means normal, so that the data are presented in the form of mean and standard deviation. Meanwhile, categorical variables such as gender, education, occupation, history of the disease, marital status, spiritual intelligence, and efficacy are presented in terms of frequency and percentage of each variable. After all the data sought is collected, the data was analyzed using Somer's correlation test with a significance level $(\alpha)$ of $5 \%$ or 0.05 .

\section{Results}

Table 1 Distribution of Respondent Characteristics

\begin{tabular}{|c|c|c|c|c|}
\hline Characteristics & Mean & SD & Total & Percentage (\%) \\
\hline Age (years) & 60.39 & 9.473 & - & - \\
\hline \multicolumn{5}{|l|}{ Sex } \\
\hline Male & - & - & 109 & 79 \\
\hline Female & - & - & 29 & 21 \\
\hline \multicolumn{5}{|l|}{$\begin{array}{l}\text { Education } \\
\text { Background }\end{array}$} \\
\hline No education & - & - & 6 & 4.3 \\
\hline Elementary School & - & - & 43 & 31.2 \\
\hline Junior High School & - & - & 17 & 12.3 \\
\hline Senior High School & - & - & 47 & 34.1 \\
\hline Higher Education & - & - & 25 & 18.1 \\
\hline \multicolumn{5}{|l|}{ Occupation } \\
\hline Jobless & - & - & 20 & 14.5 \\
\hline Labor & - & - & 8 & 5.8 \\
\hline Farmer & - & - & 17 & 12.3 \\
\hline Businesman & - & - & 17 & 23.9 \\
\hline Housewife & - & - & 11 & 8 \\
\hline Soldier. Police & - & - & 2 & 1.4 \\
\hline Private employees & - & - & 10 & 7.2 \\
\hline Public employees & - & - & 35 & 25.4 \\
\hline Etc. & - & - & 2 & 1.4 \\
\hline
\end{tabular}


Wantiah: Correlation between Spiritual Intelligence and Self-efficacy Patients with Coronary Artery Disease

\begin{tabular}{|c|c|c|c|c|}
\hline \multicolumn{5}{|l|}{ Income } \\
\hline$<$ Rp.2.000.000,00 & - & - & 76 & 55.1 \\
\hline$>$ Rp.2.000.000,00 & - & - & 62 & 44.9 \\
\hline \multicolumn{5}{|l|}{ Marital status } \\
\hline Unmarried & - & - & 0 & 0 \\
\hline Married & - & - & 129 & 93.5 \\
\hline Widow/ er & - & - & 9 & 6.5 \\
\hline \multicolumn{5}{|l|}{ Smoking History } \\
\hline Never & - & - & 63 & 45.7 \\
\hline Ever & - & - & 74 & 54.3 \\
\hline \multicolumn{5}{|l|}{ Comorbid } \\
\hline None & - & - & 53 & 38.4 \\
\hline $\begin{array}{l}\text { Hypertension (High } \\
\text { Blood Pressure) }\end{array}$ & - & - & 58 & 42.0 \\
\hline Stroke & - & - & 0 & 0 \\
\hline Diabetes mellitus & - & - & 20 & 14.5 \\
\hline Etc. & - & - & 7 & 5.1 \\
\hline
\end{tabular}

Table 2 Distribution of Spiritual Intelligence of Coronary artery disease in RSD dr. Soebandi of Jember in January-February 2020

\begin{tabular}{lcc}
\hline \multicolumn{1}{c}{ Variable } & Total $(\mathbf{n})$ & Percentage $(\mathbf{\%})$ \\
\hline Spiritual Intelligence & & \\
Low & 5 & 3.6 \\
Medium & 14 & 10.1 \\
High & 119 & 86.2 \\
Total & 138 & 100 \\
\hline
\end{tabular}

Table 3 Distribution of Self Efficacy in Patients with Coronary artery disease in RSD dr. Soebandi of Jember in January-February 2020

\begin{tabular}{|c|c|c|}
\hline Variable & Total & Percentage $(\%)$ \\
\hline \multicolumn{3}{|l|}{ Self-efficacy } \\
\hline Low & 3 & 2.2 \\
\hline Medium & 59 & 42.8 \\
\hline High & 76 & 55.1 \\
\hline Total & 138 & 100 \\
\hline
\end{tabular}

Table 4. Relationship between spiritual intelligence and self-efficacy in patients with coronary artery disease in RSD dr. Soebandi of Jember

\begin{tabular}{|c|c|c|c|c|c|c|c|c|c|c|}
\hline \multirow{3}{*}{$\begin{array}{c}\text { Spiritual } \\
\text { Intelligence }\end{array}$} & \multicolumn{6}{|c|}{ Self-efficacy } & \multirow{2}{*}{\multicolumn{2}{|c|}{ Total }} & \multirow{3}{*}{$\mathbf{P}$} & \multirow{3}{*}{$\mathbf{r}$} \\
\hline & \multicolumn{2}{|c|}{ Low } & \multicolumn{2}{|c|}{ Medium } & \multicolumn{2}{|c|}{ High } & & & & \\
\hline & $\mathbf{f}$ & $\%$ & $\mathbf{f}$ & $\%$ & f & $\%$ & f & $\%$ & & \\
\hline Low & 2 & 1.4 & 3 & 2.2 & 0 & 0 & 5 & 3.6 & $<0.001 *$ & 0.628 \\
\hline Medium & 1 & 0.7 & 12 & 8.7 & 1 & 0.7 & 14 & 10.1 & & \\
\hline
\end{tabular}


Wantiah: Correlation between Spiritual Intelligence and Self-efficacy Patients with Coronary Artery Disease

\begin{tabular}{llccccccc}
\hline High & 0 & 0 & 44 & 31.9 & 75 & 54.3 & 119 & 86.2 \\
Total & 3 & 2.2 & 59 & 42.8 & 76 & 55.1 & 138 & 100 \\
\hline
\end{tabular}

Data were collected based on respondents' answers in the questionnaire, which were 138 respondents. Table 1 provides information that the average age of the respondents was 60 years. The majority of respondents were male $(79 \%)$, one-third had primary school education $(31.2 \%)$, and had a job as a civil servant $(35 \%)$, not a few also earned $<\mathrm{Rp}$. $2,000,000(55.1 \%)$, almost all of them were married (93.5\%), 63 people had a history of ever smoking $(54.3 \%)$, and 58 people had a history of hypertension $(42 \%)$. Table 2 illustrates that most respondents have high spiritual intelligence, indicated by a percentage value of $86.2 \% .10 .1 \%$ of respondents have moderate spiritual intelligence, and another $3.6 \%$ have low spiritual intelligence.

Table 3 illustrates that most respondents have high self-efficacy, indicated by a percentage value of $55.1 \%$. As many as $42.8 \%$ of respondents had moderate selfefficacy, and another $2.2 \%$ had low selfefficacy. The data analysis results in table 4 using Somer's test d shows $p=<0.001$ with a significance level $(\alpha)$ of 0.05 , then $\mathrm{p}<\alpha$. These results mean that Ha failed to be rejected. In conclusion, there is a strong relationship between spiritual intelligence with self-efficacy in CHD patients $(p<0.05$ and $r=0.628)$ in RSD dr. Soebandi of Jember. It can then be interpreted that the higher the respondent's spiritual intelligence, the higher the self-efficacy of the respondent.

\section{Discussion}

Coronary heart disease is an acute and lifethreatening disease, but treatment requires consistent time throughout his life (Nuraeni, 2016). So that physical and psychological symptoms will appear that can worsen the patient's condition. In physical conditions in the form of chest pain, feeling tight, sexual disturbances, and weakness in activities (Rosidawati et al., 2016). Meanwhile, from a psychological perspective, anxiety and depression are also experienced by $\mathrm{CHD}$ patients, making them afraid of death (Hamzah et al., 2014). Therefore the importance of controlling risk factors and self-management to maintain the health of CHD patients.

Spiritual intelligence is a person's ability to solve problems in his life so that patients with chronic diseases can improve their health. Spiritual intelligence not only improves health but can also help patients to be able to adapt in difficult times and times of loss, new situations and get out of times of stress and fear so that they find meaning or inner purpose to adjust to new conditions or new illnesses they experience (Moallemi, 2014). Self-efficacy is an essential factor in patient self-care behavior in coronary heart patients so that they can exercise self-control and selfprevention against actions that can aggravate their condition (Alizadeh et al., 2018).

The results showed that $86.2 \%$ of respondents had high spiritual intelligence. The results showed that most CHD patients have high spiritual intelligence, where the patient has the ability that is within him to face his illness to achieve recovery. It is consistent with the research (Seed, Salari, nourisaeed, Moaddab, \& Roohi, 2014), which states that $90 \%$ of CHD patients have high spiritual intelligence. One is because of CHD is a chronic disease that threatens life suddenly with a heart attack that requires continuous treatment. It makes CHD patients have psychological stress in the form of pressure so that responses to stressors tend to increase their spirituality to make patients calmer in facing the problem (Seed et al., 2014).

Research by Nekouei et al. (2014), states that spiritual intelligence in CHD patients has an average of 75.5. Spiritual intelligence is an essential psychological protective factor in CHD patients, affecting the quality of life of CHD patients (Nekouei et al., 2014). Research by Abu et al. (2018), also states that spirituality has a positive relationship with cardiovascular patients' quality of life. In this case, CHD patients with high spiritual intelligence after patients try to seek treatment and treat it consistently, will surrender all efforts to God so as not to have a burden that can cause stress to improve the quality of life (Seed et al., 2014).

Patients with good spiritual intelligence 
have several characteristics, including knowing the deepest motives, having a high level of awareness, being responsive to themselves, taking advantage and transcend difficulties, standing up, and being different from many people. They are also reluctant to disturb or hurt people and beings others (Kurniawati, 2018). Spiritual power can reduce anxiety and help provide positive thinking to patients with chronic illness to help in decision making in treatment strategies (Tabei, Zarei, \& Joulaei, 2016). Under the study of Tajbakhsh et al.(2018), spiritual care can reduce anxiety and depression in CHD patients who will undergo Coronary Artery Bypass Graft (CABG) surgery.

The results showed that most respondents $(55.1 \%)$ had good self-efficacy. One is following research Sari, Sari, \& Pratiwi (2017), states that $62.86 \%$ of respondents with coronary heart disease have high selfefficacy. Research by Dewi et al. (2019) also reported that most patients, $80 \%$, had good self-efficacy before the percutaneous coronary intervention. After the percutaneous coronary intervention, $57 \%$ of CHD patients also had good self-efficacy. Besides, research Wantiyah, Saputra, \& Deviantony (2020) mentioned that patients with CHD had an average self-efficacy of 71.41 points, including in the good category.

The research results that the majority of patients have good self-efficacy related to self-efficacy formation factors consisting of cognitive processes, motivational processes, affective processes, and selection processes (Bandura, 1994). In the cognitive process where CHD patients think before taking action. High self-efficacy tends to be able to behave following expectations and commitment in carrying it out with high selfefficacy will encourage a mindset to achieve success, such as patients avoiding salty foods and trying to eat less salty foods.

Self-efficacy in patients with coronary heart disease is expected to increase their confidence to take precautions by having a healthy lifestyle so that they can support the improvement of their illness by controlling risk factors and maintaining their health (Shoufiah \& Noorhidayah, 2017). The existence of CHD patients' self-efficacy can respond adaptively to overcome problems by having the patient's confidence can improve health (Bandura, 1994). Research Shoufiah and Noorhidayah (2017), states that selfefficacy is related to the quality of life of patients with coronary heart disease.

Research results Wantiyah (2010), two factors can be related to self-efficacy, namely social support and emotional status. Right environmental conditions can improve selfefficacy. It happens when the family supports the treatment process, such as delivering treatment, reminding taking medication and monitoring the patient's status making patients more comfortable and having confidence in controlling risk factors to consistently undergo treatment (Puspita, Oktaviarini, Dyah, \& Santik, 2017). The emotional response of most patients with CHD in the form of anxiety, depression, and fear of conditions can affect the patient's decision-making process related to selfefficacy. Spiritual power helps patients provide calm and positive thoughts (Tabei et al., 2016).

Age is one factor that influences the self-efficacy of older individuals who have better self-efficacy in mastering coping and are more organized or directed than young people (Howsepian \& Merluzzi, 2009). Wantiyah's research (2010) states that women have a 1.19 times higher chance of efficacy compared to men in CHD patients. So that age and sex have a relationship with the level of self-efficacy of CHD patients. Also, each person has a different ability to overcome the problem.

The analysis results of the relationship between spiritual intelligence and selfefficacy in CHD patient shows a correlation between spiritual intelligence and selfefficacy. A correlation value of 0.628 baselines indicates that the higher the spiritual intelligence, the higher the self-efficacy with the correlation between influential variables. This research is also in line with the study of Nekouei et al. (2014), which shows that there is a relationship between spiritual intelligence and self-efficacy that can affect the quality of life in CHD patients.

The relationship between spiritual intelligence and self-efficacy is due to the process of forming self-efficacy. It goes through four stages, namely cognitive, 
motivation, affective and selection processes related to the presence of stressors in CHD patients, which makes patients respond cognitively by believing that if God decreases disease, undoubtedly God also decreases the cure (Gusmian, 2006). Spiritual intelligence is influenced by God's spots and brain nerves, where God has created an organ in humans so that humans recognize His God (Zohar \& Marshall, 2007). The existence of these thoughts can motivate CHD patients to continue to try to treat and improve spirituality.

Research by Nuraeni, Ibrahim, \& Rizmadewi (2013) stated that there are nine respondents of CHD patients who claim that God is a source of strength. Worship or communication with God is a source of power, hope is a source of strength, spirituality is a request for forgiveness (repentance), and sense gratitude as a strength source. It is stated that getting closer and resigning to God will strengthen CHD patients and become a source of power in their lives. Having spiritual intelligence will motivate patients in their problem-solving process to choose the best actions for their health. In the cognitive process of spiritual intelligence, the patient thinks correctly in overcoming his condition with the certainty that every illness has a cure. So that there is a motivational process that will make patients have the spirit to continue to treat and accept their current conditions (Saam \& Wahyuni, 2012).

The next formation process is the affective process, where after the patient is motivated, the patient will have confidence in his ability. However, this is influenced by others' level of success and experience that can make other patients motivated. The behavioral response will be in line with cognitive and affective reactions in the process of forming the patient's self-efficacy so that it can affect the patient's behavioral response, namely patience, endeavor, and trust in dealing with the disease. Those are the characteristics of people who have spiritual intelligence (Kurniawati, 2018).

Researchers concluded there is a positive relationship between spiritual intelligence and self-efficacy associated with factors that exist, namely the God Spot and nerve cells of the brain. The relationship between spiritual intelligence and self-efficacy can be seen from the relation of spiritual intelligence that affects the process of forming the patient's self-efficacy. Nurses are one of the factors that can help patients improve their health through the provision of holistic nursing care by paying attention to spiritual care and self-efficacy. This can be done by conducting spiritual studies in which there is spiritual intelligence in the nursing process and to identify the patient's spiritual intelligence. Spiritual intelligence that comes from within a patient can motivate patients to have confidence so that they can have functional self-efficacy through cognitive processes, motivational processes, affective, and selective. But it is also influenced by social support, emotional status, age, and gender.

\section{Conclusion}

This research concludes that most of the respondents already have spiritual intelligence and good self-efficacy. Spiritual intelligence is significantly associated with self-efficacy in CHD patients, so the higher the spiritual intelligence in CHD patients, the self-efficacy will also be higher.

This research can be used as an evaluation and input to improve the quality of services, especially the provision of holistic nursing care. Providing comprehensive nursing care to CHD patients is very beneficial because it can be used to notice how spiritual intelligence and self-efficacy are owned by patients to improve the quality of service to patients. Besides, this research has limitations to discuss the relationship between spiritual intelligence and self-efficacy and the relationship between the two variables with characteristics in CHD patients. Therefore further research can explore the factors that can be related to the involvement of spiritual intelligence and self-efficacy.

\section{References}

Abu, H. O., Ulbricht, C., Ding, E., Allison, J. J., Salmoirago-Blotcher, E., Goldberg, R. J., \& Kiefe, C. I. (2018). Association of religiosity and spirituality with quality of 
Wantiah: Correlation between Spiritual Intelligence and Self-efficacy Patients with Coronary Artery Disease

life in patients with cardiovascular disease: a systematic review. Quality of Life Research, 27(11), 2777-2797. https://doi.org/10.1007/ s11136-018-1906-4

Alizadeh, M., Feizollahzadeh, H., Abdollahzadeh, F., Hasankhani, H., Dadashzadeh, A., \& Rezaei, T. (2018). The Relationship Between Selfefficacy and Compliance With Selfcare Behaviors in Patients With Acute Coronary Syndrome After Coronary Angioplasty in Shahid Madani Hospital, 2016:A Health Belief Model. Journal of Research in Medical and Dental Science, 6(3), 415-420. https://doi. org/10.24896/jrmds.20186364

American Heart Assosiation. (2015, July 31). Coronary Heart Disease. The American Heart Assosiation. Retrieved february 19, 2020, from https:/www.heart.org/en/health-topics/ consumer-healthcare/what-is-cardiovasculardisease/coronary-artery-disease

Bandura, A. (1994). Self-Efficacy. Encyclopedia of Mental Health, 4(1994), 1994.

Bandura, A. (1994). Self-efficacy. In V. S. Ramachaudran (Ed.), Encyclopedia of human behavior Vol 4 ( pp. 71-81). Academic Press.

Dev, R. D. O., Kamalden, T. F. T., Geok, S. K., Abdullah, M. C., Ayub, A. F. M., \& Ismail, I. A. (2018). Emotional intelligence, spiritual intelligence, self-efficacy and health behaviors: Implications for quality health. International Journal of Academic Research in Business and Social Sciences, 8(7), 794809. https://doi.org/10.6007/ijarbss/v8-

i7/4420

Gusmian, I. (2006). Setiap Saat Bersama Allah: Doa-Doa Pilihan Penetram Jiwa (every moment with Allah: dua of choice). Mizan Pustaka.

Hamzah, I. F., Dewi, E. K., \& Suparno. (2014). Makna Sakit Pada Penderita Penyakit Jantung Koroner Studi Fenomenologis (meaning of pain in coronary hearth disease patients: phenomenologi study). Jurnal Psikologi Undip, 13(2), 1-10. https://doi. org/10.3906/elk-1301-164
Howsepian, B. A., \& Merluzzi, T. V. (2009). Religious beliefs, social support, self-efficacy and adjustment to cancer. Psycho-Oncology, 18(10), 1069-1079. https://doi.org/10.1002/ pon. 1442

Kementrian Kesehatan Republik Indonesia. (2014). Situasi kesehatan jantung (heart health situation). Pusat Data Dan Informasi Kementrian Kesehatan RI. Retrieved February 19, 2020, from https://www. kemkes.go.id/download.php?file=download/ pusdatin/infodatin/infodatin-jantung.pdf

Kementrian Kesehatan Republik Indonesia. (2018). RS Jantung Harapan Kita pengampu ujukan kardiovaskuler (cardiovascular referral jantung harapan kita hospital). Kementrian Kesehatan Republik Indonesia. Retrieved February 19, 2020, from https://www.kemkes.go.id/article/ view/18111200002/rs-jantung-harapan-kitapengampu-rujukan-kardiovaskular.html

Kurniawati, N. D. (2018). Pengaruh asuhan keperawatan mind-body-spiritual (MBS) Terhadap Kecerdasan Spiritual, Ekspresi Hsp 70, eNOS, VCAM-1, DAN MCP-lpada Pasien Penyakit Jantung Koroner. [Doctoral's dissertation, Universitas Airlangga]. Fakultas Kedokteran Universitas Airlangga. Retrieved February 12, 2020, from http://repository. unair.ac.id/71448/

Moallemi, S. (2014). Spiritual intelligence and high risk behaviors. International Journal of High Risk Behaviors and Addiction, 3(1), 18-20. https://doi.org/10.5812/ijhrba.18477

Nekouei, K. Z., Yousefy, A., Neshat Doost, H. T., Manshaee, G., \& Sadeghei, M. (2014). Structural model of psychological risk and protective factors affecting on quality of life in patients with coronary heart disease: A psychocardiology model. Journal of Research in Medical Sciences, 19(2), 90-98

Norouzi, M., \& Azar, F. S. (2017). Comparing spiritual intelligence and emotional expressiveness in psychosomatic patients. Journal of Research \& Health, 7(2), 745-753. https://doi.org/10.18869/acadpub.jrh.7.2.745

Nuraeni,A. (2016). Faktor yang memengaruhi kualitas hidup pasien dengan penyakit antung 
Wantiah: Correlation between Spiritual Intelligence and Self-efficacy Patients with Coronary Artery Disease

koroner (factors that affect the quality of life with coronary heart disease). Jurnal Keperawatan Padjadjaran, 4(2), 107-116. https://doi.org/10.24198/jkp.v4n2.1

Nuraeni, A., Ibrahim, K., \& Rizmadewi, H. (2013). Makna spiritualitas pada klien dengan sindrom koroner akut (meaning of spirituality with acute coronary syndrome patients). Jurnal Keperawatan Padjadjaran, 1(2), 79-87. https://doi.org/10.24198/jkp. v1n2.3

Pamungkas, R. A., \& Usman, A. M. (2017). Metodologi riset keperawatan (nursing research methodology) (1st ed. CV. Trans Info Media.

Park, N., Peterson, C., Szvarca, D., Vander Molen, R. J., Kim, E. S., \& Collon, K. (2014). Positive psychology and physical health: research and applications. American Journal of Lifestyle Medicine, 10(3), 200-206. https:// doi.org/10.1177/1559827614550277

Pencina, M. J., Navar, A. M., Wojdyla, D., Sanchez, R. J., Khan, I., Elassal, J., ... Sniderman, A. D. (2019). Quantifying importance of major risk factors for coronary heart disease. Circulation, 139(13), 1603-1611. https://doi.org/10.1161/ CIRCULATIONAHA.117.031855

Puspita, E., Oktaviarini, E., Dyah, Y., \& Santik, P. (2017). Peran keluarga dan petugas kesehatan dalam kepatuhan pengobatan penderita hipertensi di puskesmas gunungpati Kota Semarang. Jurnal Kesehatan Masyarakat Indonersia, 12(2), 25-32.

Rosidawati, I., Ibrahim, K., Nuraeni, A., Muhammadiyah, U., Keperawatan, F., \& Padjadjaran, U. (2016). Kualitas Hidup Pasien Pasca Bedah Pintas Arteri Koroner ( BPAK ) Quality of Life among Patients with Post Coronary Artery Bypass Surgery. Jurnal Keperawatan Padjadjaran, 4(2), 151-161. https://doi.org/10.24198/jkp.v4i2.238

Saam, Z., \& Wahyuni, S. (2012). Psikolog Keperawatan (1st ed.). PT Rajagrafindo Persada.

Sari, E. A., Sari, S. P., \& Pratiwi, S. H. (2017). Community Self-Eficacy of Coronary Heart Disease Based on Characteristic Risk Faktors.
NurseLine Journal, 2(2), 65-71. https://doi. org/10.19184/nlj.v3i2.8341

Seed, A. N., Salari, A., nourisaeed, A., Moaddab, F., \& Roohi, L. (2014). Spiritual intelligence and its related factors in patients with ischemic heart disease. Journal of Nursing and Midwifery Sciences, 1(3), 49-54. https://doi.org/10.18869/acadpub. jnms.1.3.49

Shoufiah, R., \& Noorhidayah. (2017). Efikasi diri berhubungan dengan Kulitas Hidup Pasien Penyakit Jantung Koroner. Kementrian Kesehatan Republik Indonesia.

Tabei, S. Z., Zarei, N., \& Joulaei, H. (2016). The impact of spirituality on health. Shiraz E Medical Journal, 17(6), 1-6. https://doi. org/10.17795/semj39053

Tajbakhsh, F., Hosseini, M. A., FallahiKhoshknab, M., Rokofian, A., Rahgozar, M., \& Davidson, P. M. (2018). The effect of spiritual care on depression in patients following coronary artery bypass surgery: A randomized controlled trial. Religions, 9(159), 2-8. https://doi.org/10.3390/ rel9050159

Wantiyah. (2010). Analisis Faktor- Faktor yang Mempengaruhi Efikasi Diri Pasien Penyakit Jantung Koroner dalam Konteks Asuhan Keperawatan di RSD $d r$. Soebandi Jember. [Master's thesis, University of Indonesia]. Universitas Indonesia. Retrieved february 8, 2020, from https://lontar.ui.ac.id/ file?file $=$ pdf $/$ abstrak-137273.pdf

Wantiyah, Saputra, M. R., \& Deviantony, F. (2020). Self-Efficacy And Health Status In Coronary Artery Disease Patients. Jurnal Ners, 15(1). https://doi.org/10.20473/ jn.v15i1.17628

Xu, X. Y., Kwan, R. Y. C., \& Leung, A. Y. M. (2019). Factors associated with the risk of cardiovascular disease in family caregivers of people with dementia: a systematic review. Journal of International Medical Research, 0(0), 1-20. https://doi. org/10.1177/0300060519845472

Zohar, D., \& Marshall, I. (2007). SQ: Spiritual Intelligence (IX). Great Britani. 